\title{
Integration of Character Values in the Standard Operating Procedure (SOP) of Registration and Data Services at the Academic and Student Affairs Bureau of State University of Medan
}

\author{
Sara Hikmayanti Sinaga \\ Postgraduate Students of Education Administration Program \\ Postgraduate Program of State University of Medan \\ hikmayanti4@gmail.com
}

\begin{abstract}
This study aims to: 1) identify the SOP components of registration and data service at the Academic and Student Affairs Bureau of the State University of Medan (SUM); 2) identify relevant character values to for the SOP of the registration and data service at the Academic and Student Affairs Bureau of the SUM; 3) developing an SOP that integrates character values in registration and data services at the Academic and Student Affairs Bureau of the SUM. This research is a descriptive qualitative research. The research sample was taken by purposive sampling by taking samples of officials in the registration and data fields at the Academic and Student Affairs Bureau of SUM. The data is collected through interview techniques, observation and document study. The results of the research are: 1) There are two SOPs developed, namely the SOP for New Student Registration of the State University of Medan via Bidik Misi selection and Non-Bidik Misi selection. The components in the SOP of the registration and data service at the Academic and Student Affairs Bureau of SUM are: a) SOP identity; b) Legal basis; c) Linkages with other SOPs; d) Executing qualifications; e) Equipment; f) Warning; g) Recording and data collection; h) Activity table; i) Purpose; j) Procedure; k) Quality control; l) References and m) Appendix, 2) Character values integrated in the developed SOP are: a) trustworthy; b) respectful; c) responsibility; d) fairness; e) caring; and f) citizenship, and 3) To develop SOPs that are integrated with character values, by adding character values to one of the components that build SOPs and to add SOP values in the SOP implementation procedures.
\end{abstract}

Keywords: SOP, character values, data and registration services

\section{INTRODUCTION}

Higher education as part of the national education system engaged in education service providers must be able to respond to environmental changes caused by increasing public knowledge as indicated by the increasingly critical attitude, increasing competition, increasing work demands and the fastchanging technology. One effort that can be done is to improve the quality of services to students and the community.
A service is a form of service provided by producers both for users of manufactured goods and services offered (Winardi, 1991: 93). Consumer satisfaction is an indicator of the assessment of the quality of services provided. Albrecht and Zemke as quoted by Dwiyanto (2006: 140-141) stated that the quality of service is the result of interaction from various aspects, namely the service system, service provider, service strategy, customer as shown in the figure below:

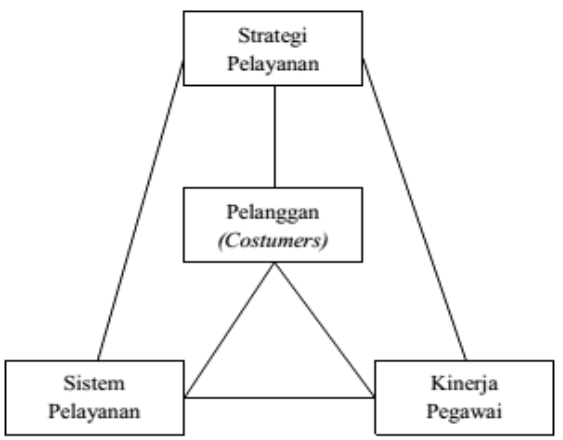

Fig 1. Service Triangle Model (Dwiyanto, 2006: 141)

A good public service cannot be separated from human resources or the performance of the employees. Therefore, if universities want to improve the service quality, one thing that needs to be reorganized or renewed is to increase the quality of the employees' performance. A good service system holds and implements clear service procedures. Besides, there is a control mechanism in the service system so that all forms of irregularities that occur will be easily discovered.

Management of service functions is outlined with standard operating procedures for services (SOP). SOP is a guideline used to ensure that all actions and decisions, as well as the use of process facilities carried out by people in the organization, run efficiently and effectively, consistently, standards and systematically. The existence of SOPs is expected to improve the efficiency and effectiveness of the service performances provided by higher education. 
The State University of Medan is a state university that organizes education and non-education study programs with the motto of The Character Building University. SUM's motto shows SUM as a university does not only have the vision to be a superior teaching and research institution but also with character. In the implementation of the program, SUM does not only consider a good quality but also good character in their services. The State University of Medan establishes six pillars of character, namely: 1) citizenship, 2) fairness, 3) respectful, 4) responsibility, 5) caring, and 6) trustworthy. The six pillars are attributes of the main character that must be achieved by SUM until 2025.

A good character educational services are a system of cultivating character values to the academic community which includes components of knowledge, awareness or willingness and actions to implement these values. Character education in higher education involves all components (stakeholders), including the education component itself, namely curriculum, learning and assessment process, relationship quality, management of learning materials, campus management, campus activities, or co-curricular activities, infrastructure empowerment, financing and work ethics of all citizens in the university.

The Academic and Student Affairs Bureau (ASAB) is the implementing element in the field of academic administration and student affairs at the State University of Medan and is under the Chancellor. Based on Permendikbud No. 148 year 2014, concerning Organization and Work Procedures of State University of Medan article 12, ASAB has the task of carrying out services in the academic field and also student and alumni coaching. The Academic and Student Affairs Bureau of SUM is responsible for: 1) establishing service policies as well as academic and student administration procedures, 2) establishing and organizing academic systems, 3) establishing and organizing evaluations of academic activities, 4) establishing and organizing registration, data and statistics of students, 5) determining and organizing the fulfillment of academic facilities, 6) establishing and organizing student interest, reasoning and information, and 7) establishing and organizing welfare services for SUM's students and alumni.

Hence, the purposes of this study are to 1) Identify the components of registration and data service SOPs at the Academic and Student Affairs Bureau of SUM; 2) Identify relevant character values to registration and data service SOPs at the Academic and Student Affairs Bureau of SUM; and 3) Develop SOPs that integrate good character values in registration and data services at the Academic and Student Affairs Bureau of SUM.

\section{LITERATURE STUDY}

According to the Indonesian Dictionary, integration is an assimilation to become a whole or rounded entity. Integration comes from English "integration" which means perfection or overall. Integration comes from an adjective "integer", which means "intact", "no defect", "no crack", "no chipped", "intact" (Soedarno 1992: 38). Etymologically, integration comes from the Latin word which means giving a place to an element of a whole. From the verb, formed the noun integrity, with the meaning of unity or undivided. Therefore, the term integration means making certain elements into a single and unified whole (Sadilah, 1997: 24).

A character is a reflection of human self-related to a person's behavior which becomes a habit in their daily life, either good or bad. It depends on the character development in their environment. As expressed by Aristotle (in Gunawan, 2012: 23), a character is closely related to habits that are often manifested in behavior. According to Thomas Lickona (in Gunawan, 2012: 23), "education is to shape one's personality through ethical education, the results of which are seen in a person's real actions, namely good behavior, honest responsibility, respect for the rights of others, hard work, and etc".

According to Soemarno (in Merli, 2011: 25), a character is the inner values within us through education, experience, experimentation, sacrifice, and environmental influences, combined with the values within human beings into a kind of intrinsic value that manifests in the fighting power system underlying our thoughts, attitudes, and behavior.

Another view of the character put forward by Kusuma (2007: 80) as follows: The term character is considered the same as personality. Personality is considered as a feature or characteristic or style or unique attribute of a person that comes from the forms received from the environment. The term character is also understood by someone who has a personality. Ministry of National Education (2010) as stated in the national book on national character development in 20102025 as follows: character development, which is an effort to realize the mandate of Pancasila and the Preamble of the 1945 Constitution, is motivated by the reality of national problems that develop at this time, such as: disorientation and unreached value of Pancasila; limitations of integrated policy goals in realizing the values of Pancasila; shift of ethical values in the nation and state life; fading awareness of cultural values; threat of national disintegration; and weakening of the nation's independence.

Mc. Elmeel (in Pangaribuan, et al., 2012: 18) explained that the characters regard to attributes, "caring, confidence, courage, curiosity, flexibility, friendship, goal setting, humility, humor, initiative, integrity, patience, perseverance, positive attitude, problem solving , self discipline, teamwork". The Josephson Institute (in Pangaribuan, et al, 2012: 23) proposes six pillars of character, namely 1) trustworthy; 2) respectful; 3) responsible; 4) fairness; 5) caring; 6) citizen.

Furthermore, Josephson Institute (in Pangaribuan, et al., 2012: 24) describes the six pillars as follows:

1) People who can be trusted are people who are honest, do not steal, do not cheat, are reliable, have the courage to do the right thing, build a good reputation, loyal to family, friends and the country;

2) Respectful people must treat others with respect, follow the golden rule, be tolerant and accept differences, conduct courtesy, use a good language in communication, pay attention to other people's feelings, not threatening, 
beating or hurting others, make peace agreement against others who commit anger, humiliation and who often oppose consensus;

3) A responsible people do the plan ahead, diligently and always trying, do the best, control themselves, be disciplined, think before an act and consider the consequences, be responsible for words, actions and attitudes and set a good example for others;

4) Fair people play according to the rules, sharing and taking turns, open-minded, listen to others, do not take advantage of others, not blaming others, not carelessly, treating everyone fairly;

5) People who care are loving and caring, expressing gratitude, forgiving others, helping people in need;

6) People who realize themselves as citizens are willing to cooperate, live clearly and formally, engage in affairs that make people better, become good neighbors, obey laws and regulations, respect the government (authority), protect the environment.

The preparation of the Standard Operating Procedure (SOP) is one of the ways that an organization can take to improve performance. The SOP is a series of written instructions that are made regarding various processes of organizing organizational activities, how and when to do, where and by whom is carried out (Permenpan \& RB number 32 of 2012). Laksmi, et al (2008: 52) defines SOP as a document relating to procedures that are carried out chronologically to complete a job that aims to obtain the most effective work from workers at the lowest cost. In a simpler language, Sailendra (2015: 11) explains the SOP as a guide that is used to ensure the operational activities of the organization or company run smoothly.

Moekijat (2008) further explained the principles of SOP as follows: 1) simple, so that it is easy to monitor, 2) specialization is used as well as possible, 3) prevention of writing, movement or unnecessary activities, 4) try to get the best workflow well and prevent any obstacles, 5) prevent duplication of work, 6) there are minimal exceptions to the rules, 7) prevent unnecessary checks, 8) SOPs provide continuous supervision of work done, 9) use of office's machines as well as possible, 10) use the best sequence of work, 11) every work completed must advance the work by taking into account the objectives, 12) administrative work must be held to a minimum, 13) make the best use of the exclusion principle.

In Permenpan \& RB No. 32 year 2012 concerning Guidelines for Preparing Operational Standards Procedures for Government Administration, the principles of SOP preparation are explained as follows:

1) Ease and clarity. Standardized procedures must be easily understood and applied by all regulations even for someone who is completely new in carrying out their duties;

2) Efficiency and effectiveness. Standardized procedures must be the most efficient and effective procedure in the process of carrying out tasks;
3) Alignment. Standardized procedures must be in harmony with other relevant standard procedures;

4) Measure. The output of standardized procedures contains a certain standard of quality or quality that can be measured for the achievement of its success;

5) Dynamic. Standardized procedures must be quickly adapted to the needs of improving the quality of services developed in the administration of government;

6) Oriented to users or parties served. Standardized procedures must consider user needs (customer needs) so that they can satisfy users;

7) Legal compliance. Standardized procedures must meet applicable government regulations and regulations;

8) Legal certainty. Standardized procedures must be determined by the leader as a legal product that is obeyed, implemented and becomes an instrument to protect the regulations or implementers of possible lawsuits.

In addition to the drafting principle, it was also explained about the principles of implementing SOP as follows:

1) Consistent. SOPs must be carried out consistently from time to time, by anyone, and in relatively similar conditions by all levels of government organizations;

2) Commitment. SOPs must be carried out with full commitment from all levels of the organization, from the lowest and highest levels;

3) Continuous improvement. The implementation of the SOP must be open to improvements to obtain procedures that are truly efficient and effective;

4) Binding. SOPs must bind the executor in carrying out their duties in accordance with the standard procedures that have been established;

5) All elements have important roles. All officers carry out certain roles in each standardized procedure. If a particular apparatus does not carry out its role properly, it will disrupt the entire process, which ultimately also affects the disruption of the process of governance;

6) Well documented. All standardized procedures must be well documented so that they can always be used as references or references for all parties that need them (Permenpan \& RB number 32 of 2012).

The purpose of creating an SOP according to Ekotama (2015: 42) is to simplify our work so that it is only focused on the core, fast and precise. Purnamasari (2015: 16) said the objectives and functions of SOPs are as follows: 1) to provide a recording of activities and operations practically, 2) to clearly know the roles and functions of each position in the organization, 3) to establish discipline for all members of the organization both in institutions, organizations and companies, 4) to maintain a consistent level of performance in each of its work units, 5) to expedite work or tasks for employees, 6) to be used as a strong legal basis for taking action when there is a misuse/abuse of SOP authority, 7) to provide convenience in filtering, analyzing and disposing of things or work that is not in accordance with procedures, 8) to minimize errors/failures, doubt/duplication and inefficiency, 9) to improve the quality or performance of the employee itself, 10) to help strengthen company regulation, 11) to ensure the efficiency of each 
operational activity, 12) to describe all equipment for the effectiveness of training programs, 13) to provide convenience in carrying out work so that all employees are aware of job responsibilities, understand and know their rights and obligations, and 14) to protect organizations/work units and employees from malpractice or other errors.

In the Indonesian Dictionary (1999), service is said to help prepare what someone needs. According to Gronroos (in Ratminto \& Winarsih, 2009), service is an activity or a series of activities that are invisible (non-palpable) and occur due to the interaction between consumers and employees or other things provided by the service company intended to solve the problem of the consumer/customer. Teguh (2002) defines service as an activity or benefit offered by a party to another party which basically does not produce ownership.

Moenir (2000) states that service is a process of meeting needs through the activities of others directly. Understanding this process is limited in management activities for the achievement of organizational goals. Bharata, as quoted by Erlando (2004), states that service is an activity or sequence of activities that occur in direct interaction between a person and another person or between a person and machinery physically which provide customer satisfaction.

Services have five dimensions: tangible, reliability, responsiveness, assurance and empathy. Tangible (physical evidence) is the presence of supporting facilities, officers or means of communication that accompany the product. Reliability is the ability to provide promised services immediately, accurately and satisfactorily. Responsiveness is the desire of staff and employees to assist consumers and provide responsive services. Assurance includes the knowledge, ability, politeness and trustworthiness of the staff, free from danger, risk or doubt. Empathy includes the ease of relationships, good communication, personal attention and understanding the needs of consumers (Zeithaml et al., 1990: 26).

The State University of Medan (SUM) as a unit implementing education activities has the vision to become a university that excels in the fields of education, industrial engineering, and culture. In connection with this, SUM developed a mission through the implementation of education, research and community service, expanding SUM to become a superior teaching and research institution, developing an entrepreneurial culture, fostering scientific resources among SUM, fostering an academic atmosphere and a healthy organization.

In order to actualize the vision and mission, SUM needs to improve the service delivery process to better reflect a reliable and trusted institution. In this case, efforts to improve employee performance must be carried out through the implementation of dynamic and sustainable bureaucratic reform.

The Academic and Student Affairs Bureau (ASAB) is the implementing element in the field of academic administration and student affairs at State University of Medan, positioned under the chancellor, based on Minister of Education Regulation No. 148 year 2014 concerning Organization and
Work Procedures of State University of Medan article 12, having the task of carrying out services in the academic field, coaching student and alumni. Furthermore, Article 13 states that in carrying out its duties, ASAB functions are as follows: 1) implementation of education, research and community services; 2) evaluation of education, research, and community service; 3) registration and student data; 4) implementation of fostering students' interests, talents, and welfare; 5) implementation of the preparation of alumni data and other alumni affairs; 6) coordination and implementation of domestic and foreign cooperation affairs.

The ASB of SUM has the following task details:

1. to establish service policies as well as academic and student administration procedures,

2. to establish and administer an academic system,

3. to establish and carry out an evaluation of the implementation of academic activities,

4. to determine and administer registration, data and student statistics,

5. to determine and organize the fulfilling of academic facilities,

6. to establish and organize affairs of student interest, reasoning and provide information,

7. to establish and organize SUM student and alumni welfare services.

The detailed tasks of the Academic Division include:

1. to carry out the preparation of the work program for the academic division;

2. to carry out an academic data analysis;

3. to carry out the preparation of academic calendars as well as academic and student guidelines;

4. to carry out the management of data and information on education, research and community service;

5. to carry out the student admission and registration matters;

6. to carry out the preparation of graduation ceremony, anniversary, scientific oration, professor's inauguration ceremony, and other scientific meetings;

7. to carry out the administration of student graduation;

8. to carry out the preparation of the needs and utilization of academic facilities plan;

9. to organize data and information on permit and study program accreditation;

10. to carry out the preparation of materials facilitating the accreditation of study programs and institutions;

11. to carry out the preparation of evaluation material for academic activities and academic facilities;

12. to carry out storage and maintenance of section documents; and the preparation of the division report.

Detailed tasks of Registration and Data Sub-division are:

1. to do the sub-division work program preparation;

2. to arrange materials for the implementation guidelines for student admission and registration;

3. to prepare for the implementation program of the new student admissions;

4. to conduct student registration matters; 
5. to prepare the granting of the student's ID, student card, study plan card, and study result card;

6. to do data collection of students and graduates;

7. to do data processing and compiling of student statistics;

8. to do storage and maintenance of sub-division documents; and

9. to write sub-division reports

\section{METHODOLOGY}

To determine the subject of the study, the writer used a purposive sampling technique. Purposive sampling is a data source sampling technique with certain considerations, namely those who know best about the problem to be studied. The arrangement of the number of samples according to Nasution (in Sugiyono, 2015: 302) is considered to be adequate if it has reached the level of "redundancy" (the data is saturated). The subjects of this study were people or informants who were very competent in providing data and information about the implementation of registration and data SOP fields. Therefore, the subject of this research was the officials and staff of registration and data consisting of eight people, namely: 1) Head of Academic and Student Affairs Bureau; 2) Head of Academic Division; 3) Head of Registration and Data Subdivision; 4) Staff for registration and data sub-division, totaling 6 (six) people.

The type of research used is descriptive qualitative research. This research seeks to describe a symptom, happening, and event that occurs at the moment (Sudjana and Ibrahim, 1989: 65). According to Ali (1982: 120), descriptive research methods are used to solve as well as answer the problems that occur in the present. According to Sugiyono
(2010: 15), qualitative research methods are research methods based on the philosophy of positivism, used to examine the condition of objects naturally, (as opposed to experimentation) where researchers are key instruments, data source sampling is done positively and snowball, collection techniques are triangulated, data analysis is inductive/qualitative, and the results of qualitative research emphasizes meaning over generalization.

According to Nazir (1988: 73-74), there are several general steps in descriptive research methods, namely: 1) selecting and formulating problems, 2) determining the objectives of the research carried out, 3) providing limitation of the area to which the research is carried out, 4) formulating theoretical framework and conceptual framework, 5) tracing literature sources, 6) formulating hypotheses, 7) doing fieldwork to collect data, 8) making tabulations and statistical analysis of the data obtained, 9) interpreting results, 10) making generalizations and deduction.

\section{RESULT AND DISCUSSION}

The developed SOP is anSOP that is owned by the Academic and Student Affairs Bureau of State Unversity of Medan in the Registration and Data Division. Based on the data obtained from the documentation study, there are two SOPs that have been established, namely the SOP for the New Student Registration for the State University of Medan via Bidik Misi Program and the SOP for the New Student Registration for the State University of Medan via Regular Admission.

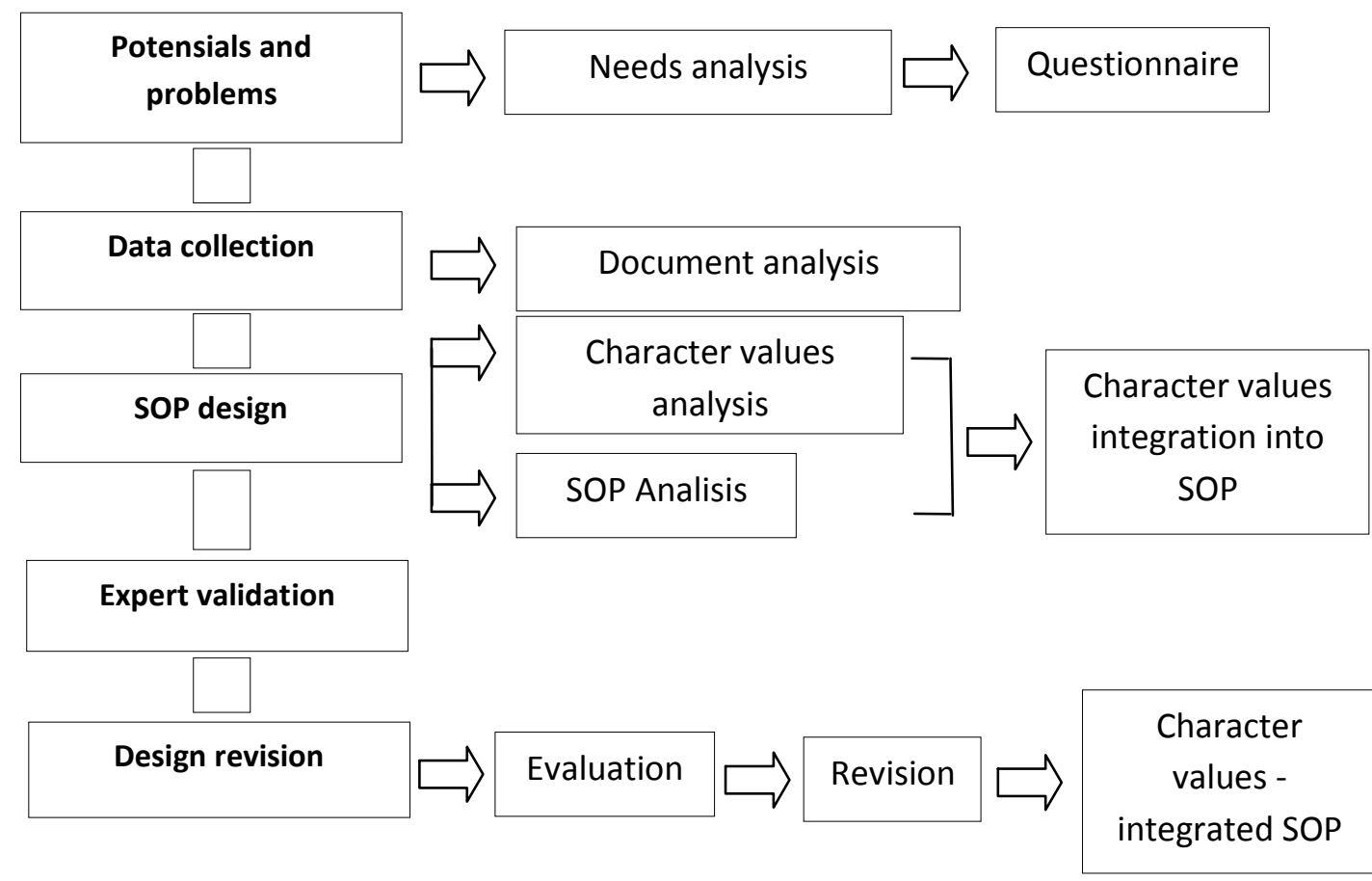

Fig 2. Design of SOP Development 
The SOP for the New Student Registration for the State University of Medan via Bidik Misi Program is a series of procedures that are carried out in the registration process for new students, both SNMPTN, SBMPTN and UM who take Bidik Misi scholarships. While the SOP for the New Student Registration for the State University of Medan via Regular Admission is a series of procedures that are carried out in the registration process of new students both SNMPTN, SBMPTN and UM who do not take the Bidik Misi scholarship.

The components contained in the SOP from the Data and Registration Division of The Academic and Student Affairs Bureau, State University of Medan include:

1. SOP identity, including SOP Number, manufacture date, revision date, effective date, authorized by, and SOP name;

2. Legal basis, containing the legal basis for the making of the SOP;

3. Linkages, the part that explains the connection between SOPs and other SOPs;

4. Executing qualifications, including the qualifications of employees involved in the SOP procedure series;

5. Equipment, containing data of equipment needed in the SOP procedure series;

6. Warning, containing matters that cause the process in the SOP procedure series to not be continued/carried out;

7. Recording and data collection, containing archiving information;

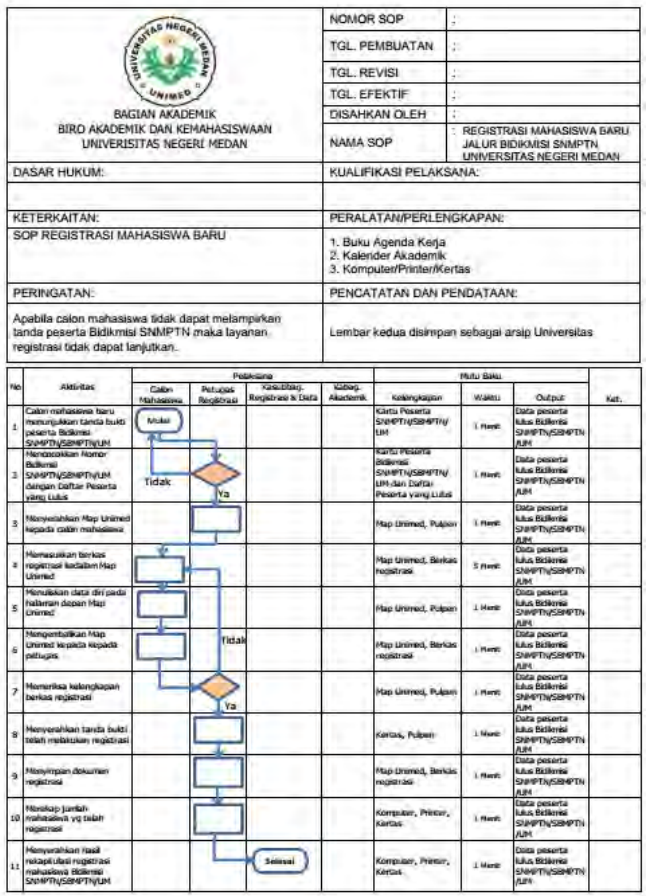

8. Activity table, containing details of SOP implementation activities consisting of activities carried out, implementers and standard quality determined. Details of activities carried out by each implementer are described in a flowchart.

9. Purpose, containing an explanation of the intended purpose of the SOP and refers to the legal basis used;

10. Procedure, consisting of six parts, namely explaining the application and scope of the SOP in question, a summary of the work procedures performed, the definition of the SOP keywords referred to, the qualifications and responsibilities of employees that explain the qualifications of the employees involved in the SOP procedures and the responsibilities assumed, an explanation of the steps that must be carried out by the officer/employee involved, as well as the management of documents containing any documents used in the implementation of the SOP;

11. Quality control, containing policies/procedures to maintain the level of service quality;

12. References, containing references used in making the SOP.

13. Attachment, containing output files from the SOP.

SOP for the New Student Registration for the State University of Medan via Bidik Misi Program that has been developed by the Registration and Data Division can be seen in Figure 1 as follows:

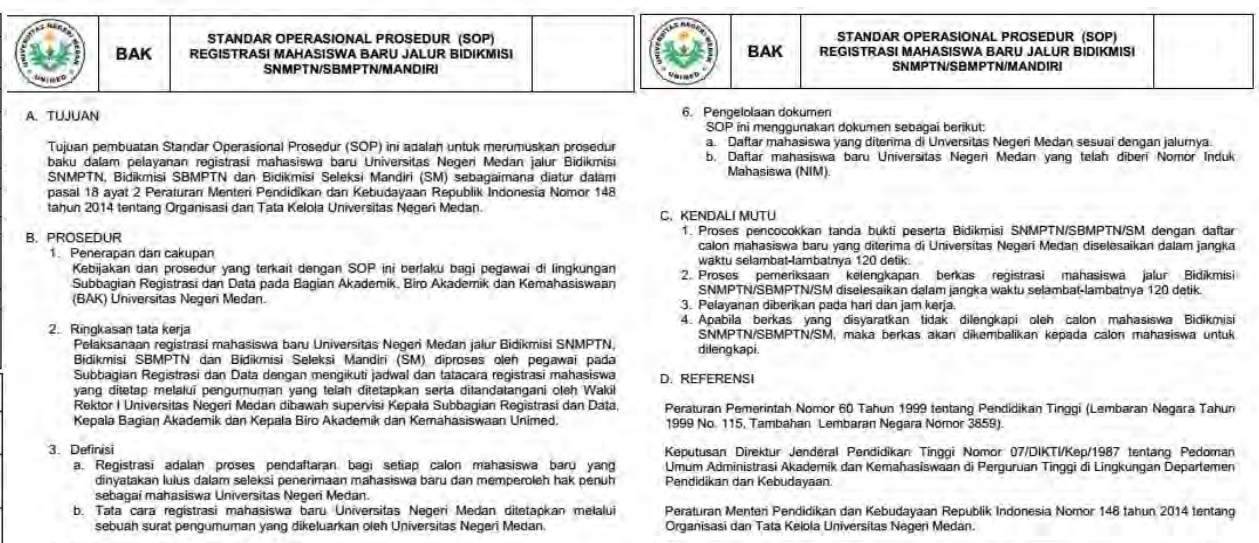

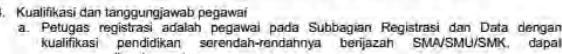

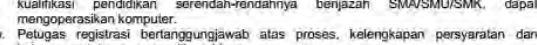

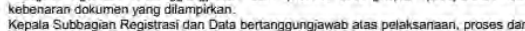
Kepala subsagian Rega
laporan hasi kejanya.

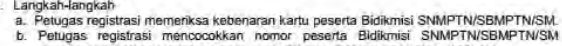

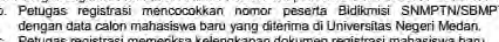

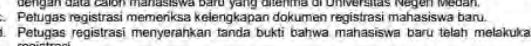

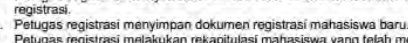

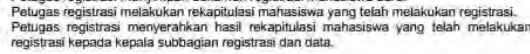

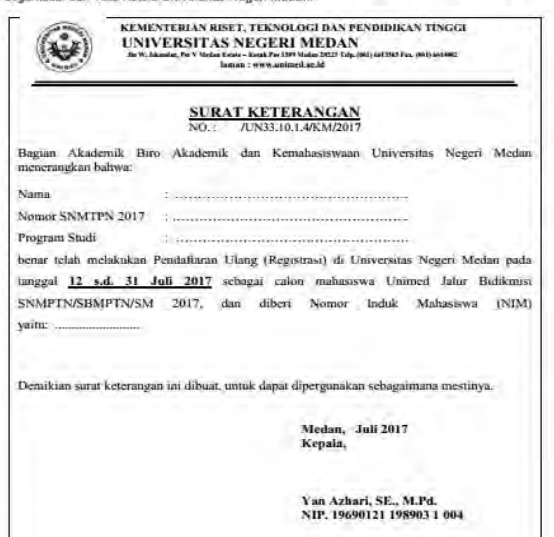

Fig 3. SOP for the New Student Registration for the State University of Medan via Bidik Misi Program 
The State University of Medan aspires to be "the character building university" by implementing strategies namely: developing a grand design that integrates character education, integrating character in all academic and administrative activities on campus and off campus, and ensuring all lecturer, staff and students have character standards that are understood and done together both on campus and off campus.

TABLE 1. Six Pillars of Character
There are six pillars of character applied in State University of Medan, namely 1) trustworthy; 2) respectful; 3) responsible; 4) fairness; 5) caring; 6) citizen. The six pillars are explained in Table 1. as follows:

\begin{tabular}{|l|l|l|}
\hline No & Pillars of Character & \multicolumn{1}{c|}{ Indicators } \\
\hline 1 & Trustworthy & $\begin{array}{l}\text { honest, do not steal, do not cheat, reliable, have the courage to do the right thing, build a good } \\
\text { reputation, loyal to family, friends and the country }\end{array}$ \\
\hline 2 & Respectful & $\begin{array}{l}\text { Treat others with respect, follow the golden rule, tolerant and accept differences, conduct } \\
\text { courtesy, use a good language in communication, pay attention to other people's feelings, not } \\
\text { threatening, beating or hurting others, make peace agreement against others who commit } \\
\text { anger, humiliation and who often oppose the consensus }\end{array}$ \\
\hline 3 & Responsible & $\begin{array}{l}\text { plan ahead, diligently and always trying, do the best, self-control, discipline, think before act } \\
\text { and consider the consequences, responsible for words, actions and attitudes and set a good } \\
\text { example for others }\end{array}$ \\
\hline 4 & Fairness & $\begin{array}{l}\text { play according to the rules, sharing and taking turns, open-minded, listen to others, do not take } \\
\text { advantage of others, not blaming others, not carelessly, treating everyone fairly }\end{array}$ \\
\hline 5 & Caring & $\begin{array}{l}\text { loving and caring, expressing gratitude, forgiving others, helping people in need } \\
\text { willing to cooperate, live clearly and formally, engage in affairs that make people better, } \\
\text { become good neighbors, obey laws and regulations, respect the government (authority), } \\
\text { protect the environment }\end{array}$ \\
\hline 6 & Citizen &
\end{tabular}

One of the strategies to realize the "character building university" as mentioned earlier is to integrate character in all academic and administrative activities on campus and off campus. One of the implementations is to integrate character values in the SOPs. In this study, SOPs that are developed and integrated are SOPs owned by the Registration and Data division, namely SOP for the New Student Registration for the State University of Medan via Bidik Misi Program and the SOP for the New Student Registration for the State University of Medan via Regular Admission. By examining the existing SOPs, integrating the character values into one of the components added to the previous SOP is adding the "character value" component before the reference component. In addition to adding components in the SOP, character values are also integrated into the activity table by adding service character items with detailed character values and indicators. Character values that appear only in activities with direct involvement by employees. The addition of character values can be seen in Figure 2 as follows:
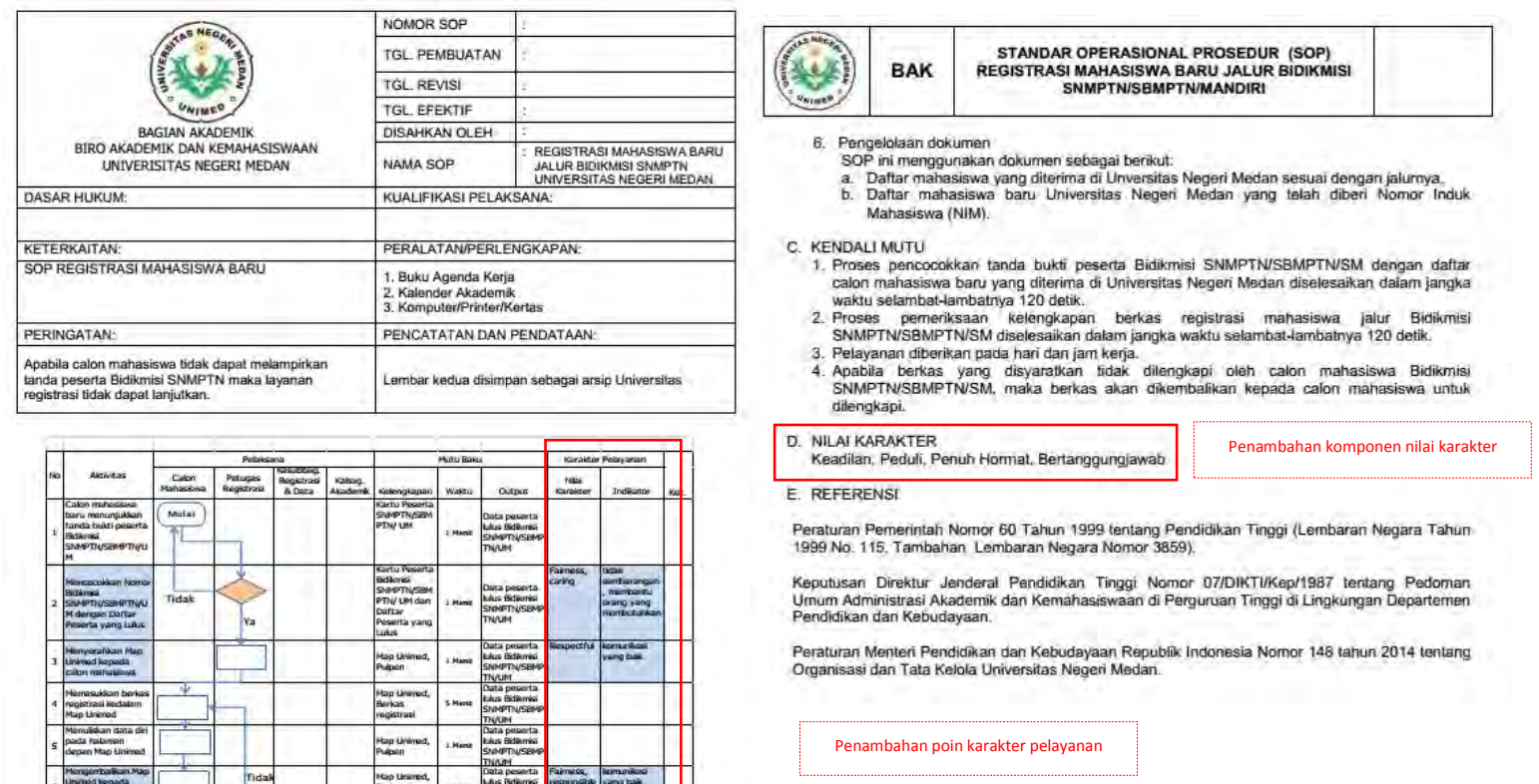

Fig 4. Character values-Integrated SOP

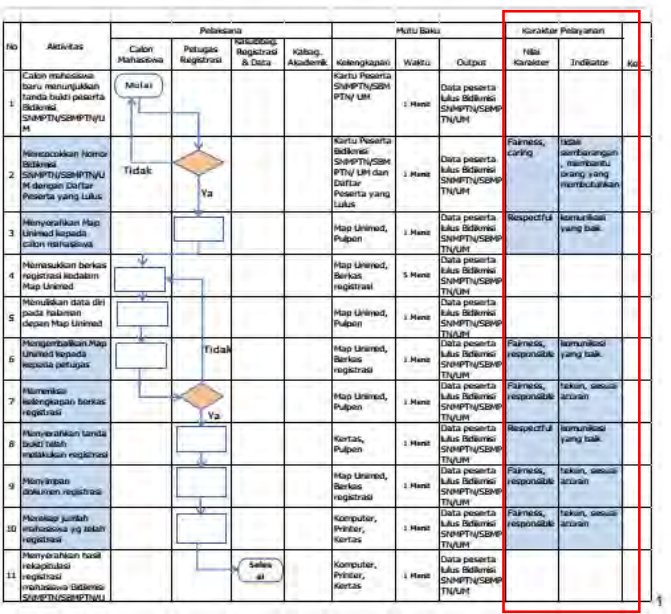




\section{CONCLUSION}

SOPs that are developed and integrated with character values are the SOP for the New Student Registration for the State University of Medan via Bidik Misi Program and the SOP for the New Student Registration for the State University of Medan via Regular Admission.

The components contained in the SOP of the Data and Registration service of the Academic and Student Affairs Bureau of State University of Medan are: 1) SOP identity; 2) Legal basis; 3) Linkages; 4) Executing qualifications; 5) Equipment; 6) Warning; 7) Recording and data collection; 8) Activity table; 9) Objectives; 10) Procedure; 11) Quality control; 12) References, 13) Attachments.

SOP is developed by integrating six character pillars, namely 1) trustworthy; 2) respectful; 3) responsible; 4) fairness; 5) caring; and 6) citizens into the SOP component by adding character values to be one of the components that build SOPs and add SOP values in the SOP implementation procedures.

\section{REFERENCES}

[1] A. Kusuma, Doni, 2007. Pendidikan Karakter; Strategi Mendidik Anak di Zaman Global, Jakarta: Grasindo

[2] Dekdikbud, 1999. Kamus Besar Bahasa Indonesia. Jakarta: Balai Pustaka

[3] Dwiyanto, Agus, 2006, Mewujudkan Good Governance Melalui Pelayanan Public, Yogyakarta : UGM Press

[4] Erlando, Analisis Pengaruh Pelayanan Prima (Service Excelence) Terhadap Kepuasan Pelanggan (Studi Pada SPBU Pertamina 3412708)

[5] Gunawan ,Heri. 2012. Pendidikan Karakter Konsep dan Implementasi . Bandung: Alfabeta

[6] Moenir. 2000. Manajemen Pelayanan Publik. Bina Aksara. Jakarta

[7] Nazir,M. 1988. Metode Penelitian, Jakarta: Ghalia Indonesia

[8] Pangaribuan Wanapri. 2012. Pendidikan Karakter di Perguruan Tinggi, Konsep dan Implementasi. Medan: Unimed Press

[9] Purnamasari, Evita P. Panduan Menyusun Standard Operating Procedure (SOP). Yogyakarta: Kobis. 2015

[10] Ratminto \& Atik Septi Winarsih. 2009. Manajemen pelayanan. Yogyakarta: Pustaka Pelajar

[11] Sailendra, Annie. 2015. Langkah-langkah Praktis Membuat SOP. Yogyakarta: Trans Idea Publishing.

[12] Sudjana, Nana dan Ibrahim. 1989. Penelitian dan Penilaian Pendidikan. Bandung: Sinar Baru.

[13] Teguh, Baroto. 2002. Perencanaan dan pengendalian Produksi. Jakarta : Ghalia Indonesia

[14] Winardi. 1991. Marketing dan Perilaku Konsumen. Bandung : Mandar Maju.

[15] Zeithaml, V.et al.1990. Delivering Quality.5th Edition, Free Press A Division of Macmillan Inc 